\title{
A VILÁG BIZONYOS SZIMMETRIÁJA
}

A Typotex Kiadó gondozásában megjelent, $A$ világ bizonyos szimmetriája címü mü a kora újkori csillagászat tudománytörténeti fejlődését mutatja be, ahogy arról a kötet alcíme - A kora újkori csillagászat története válogatott források tükrében - is tanúskodik. A tanulmánygyüjtemény Vassányi Miklós (Károli Gáspár Református Egyetem Szabadbölcsészet Tanszék, docens; filozófus, nyelvész, történész) és Kutrovátz Gábor (Budapesti Műszaki és Gazdaságtudományi Egyetem Filozófia és Tudománytörténet Tanszék, docens; filozófus, tudománytörténész) közös munkájának eredménye, melyben a két, filozófiában és tudománytörténetben jártas szerző gondosan válogatott forrásokon keresztül vezeti végig az olvasót a természettudományok, közelebbről a csillagászat fejlődésének nagy tudománytörténeti ívén. A szerzők szakmai felkészültségét nemcsak a szövegközpontúság, hanem a forrásokhoz mellékelt és tudományos gondossággal kidolgozott tanulmányok is szemléltetik, amelyek nemcsak a szakértő közeg, hanem a laikus olvasó számára is érthetővé és élvezhetővé teszik a téma feldolgozását. Szerencsémre alap- és mesterképzésem során is részt vehettem Vassányi Miklós tanár úr Vallás és természettudomány címet viselő kurzusán, melyen elsőkézből tapasztalhattam meg a szerzőpáros egyik tagjának téma iránti elhivatottságát és felkészültségét. A könyv azonban nem jöhetett volna létre a csillagász végzettségű Kutrovátz Gábor asztronómiai, fizikatudományi szaktudása nélkül sem, amely a bevezető tanulmányokon kívül a szakszerü jegyzetapparátusban is megnyilvánul. A kötet mások munkáját dicséri. A forrásgyüjteményben ugyanis közremüködött Erdei Ildikó, Nádasdi Nóra és Suszta Laura is.

A világ bizonyos szimmetriája hat fejezetében hat különböző szerző kapott helyet. Ahogy Láng Benedek tudománytörténész fogalmaz a kötet előszavában: „E könyv szereplői a tudomány történetének legismertebb, legtöbbet hivatkozott szerzői közé tartoznak [...].” (7.) Olyan nagy tudósok munkái találhatók a különböző fejezetekben, mint Nicolaus Copernicus, Michael Mästlin, Johannes Kepler, Galileo Galilei, René Descartes és Isaac Newton. Úgy gondolom, hogy a névsor önmagában is jelzi az alkotás tudományos horderejét. Szintén a szerzők alapos felkészültségét dicséri, hogy az adott gondolkodók munkásságát részletes háttértörténeti ismertetés mellett dolgozzák fel, ezzel elösegítve a témán belül való tájékozódást. A Sidereus nuncius, a Principia vagy a Narratio prima elemzése mellett olyan érdekességek ismertetésére is helyet találtak, mint a távcső feltalálásának története. Ezen felül a gyűjitemény függelékei között található egy csillagászati fogalomtár, amelyet maga Kutrovátz Gábor állított össze. Emellett helyet kapott a Principia mathematica későbbi kiadásainak részét képező Scholi- 
um generale teljes latin szövege is, amelyet a kiváló teológus és Newton-szakértö, Erdei Ildikó dolgoz fel, akinek Kora újkori teológia és filozófia előadás-sorozatán jómagam is részt vehettem. Szakmailag különösen nagy örömmel láttam, hogy a szerzők nagy hangsúlyt fektettek Newton teológiai munkásságának bemutatására is a természettudományos jelentősége mellett, hiszen Newton ezen oldalát még napjainkban sem teljesen ismeri a tudományos és laikus közvélemény. Ezért is kimagasló A világ bizonyos szimmetriájának progresszivitása.

A tanulmány- és forrásgyüjtemény nemcsak a tudománytörténet, de a kutatásmódszertan szempontjából is fontos. A kategorizáló gondolkodás tükrében ugyanis hajlamosak vagyunk úgy tekinteni gondolkodókra és tudományágakra, mint statikus jelenségekre. Ennek folyományaként történelemszemléletünkből gyakran kivész a dinamizmus. A fent említett szerzők vizsgálata során Vassányi Miklós és Kutrovátz Gábor kiválóan szemléltetik, hogy a gondolkodás és a tudomány fejlődése nemcsak általánosan, hanem egyénenként is egy hosszas folyamat eredménye. „A történelem nagy gondolkodói és tudósai nem voltak mindig szobrok" - fogalmazott erről egy kedves régi tanárom. A folyamat, melynek során egy tudományos felfedezés létrejön, adott esetben épp olyan jelentős tanulságokkal bírhat, mint maga a gondolat. A kötet szerzői ezt szem előtt tartva dolgozták ki és állították össze ezt a terjedelemben és szakértelemben is bővelkedő művet, amely forrásgyüjtemény szerepkörének eleget téve, nagyban megkönnyítheti a kutatók és a tanulni vágyók munkáját, mivel egy egységes tematika mentén gyüjti össze a kapcsolódó szerzőket. Ilyen módon pedig a különféle tudománytörténeti kurzusok primer és szekunder irodalmának szerves részét képezheti a közeljövőben. Kutatóként mindig örömmel kell fogadnunk a hasonló alapossággal és rendszerességgel kidolgozott forrásgyüjteményeket, amelyek egy adott téma komplex lefedésére törekednek. Nagy örömömre szolgált, hogy a nyár folyamán az elsők között olvashattam $A$ világ bizonyos szimmetriáját.

(Vassányi Miklós - Kutrovátz Gábor: A világ bizonyos szimmetriája. A kora újkori csillagászat története válogatott források tükrében. Tanulmány-és forrásgyüjtemény. Budapest: Typotex, 2021)

Scheffer Kevin Eötvös Loránd Tudományegyetem Bölcsészettudományi Kar Filozófiatudományi Doktori Iskola 